\title{
INFERENCES IN ADVERTISEMENTS: EXEMPLIFYING WITH RELEVANCE THEORY
}

\author{
Jane Rita Caetano da Silveira \\ Ana Maria Tramunt lbaños* \\ Pontifícia Universidade Católica do Rio Grande do Sul \\ Porto Alegre, Brasil
}

\begin{abstract}
Ever since Sperber and Wilson presented their theory of relevance, a lot of work has been done to corroborate or to refute it as the best available communication theory. What is known is that throughout the years not only linguists but cognitive theorists in general have applied the principles of Relevance theory to explain different phenomena concerning aspects of human communication. Our paper is no different. It discusses the possibilities of analysing advertisements with verbal and visual elements through relevance theory, specifically in terms of what triggers inferential comprehension in such pieces. The three pieces analysed do not engage in selling marketing products, but they sell ideas that become ostensive by means of merging visual and linguistic inputs to inferential understanding of what they mean.
\end{abstract}

Keywords: Relevance Theory. Advertising. Communication. Inference.

To engage the written word means to follow a line of thought, which requires considerable powers of classifying, inference-making and reasoning.

Neil Postman

\section{INTRODUCTION1,2}

When a competent user of any language sees an advertisement text with visual and verbal elements, inserted in an everyday context, it is normally expected that he should read and understand it in the sense of going beyond mere decoding of communicative signs, allowing for proper interpretation of the message intended by the communicator. Fundamental questions for those who study language would be "how does it happen?" or "What triggers understanding?"

Our paper aims to analyse advertising pieces following Sperber and Wilson's relevance theory $(1986 ; 1995)$ to illustrate how spontaneous inferential comprehension occurs through imagery and linguistic resources. One of the merits of this theory is that it merges decoding processes with inferences in, among others, a deductive system of cognitive nature which presupposes a new concept of context within both

\footnotetext{
* Professors of Linguistics and PhD in Letters/Linguistics at Pontifical Catholic University of Rio Grande do Sul - PUCRS, Brazil. E-mail addresses: jane.silveira@pucrs.br and atibanos@pucrs.br

1 The text was translated by Mônica Monawar. Ph.D student of Linguistics, Pontifícia Universidade Católica do Rio Grande do Sul - PUCRS, Brazil. E-mail address: monawar.monica@gmail.com.

${ }^{2}$ We would like to thank Billy Clark for his reading and important ideas to this paper. Any fault is ours.
} 
representational and information processing levels. According to Sperber and Wilson, potential inferences or interpretive hypotheses are constructed by the receiver from overt communication situations (in this specific case, intrinsic to the nature of advertising campaigns whose purpose is to sell a product, a service, or an idea). The receivers are responsible for inferentially creating their own assumptions, related to the intention of the communicator, seeking a number of cognitive and contextual effects without expending more effort of mental processing than is necessary, through perception (sensory-perceptual stimuli), linguistic decoding, encyclopaedic knowledge (information stored in memory) and deductive and non-demonstrative reasoning. Our paper is organized as follows. In section 2, we discuss relevance, communication and advertising. Section 3 shows possibilities of analysing the pieces within the framework adopted in section 2. Section 4 is the conclusion of the paper.

\section{ON RELEVANCE AND ADVERTISING}

As stated before, our paper discusses the possibilities of analysing advertisements with verbal and visual elements through relevance theory, specifically in terms of what triggers inferential comprehension in such pieces. To do so, we follow a) some fundamental processes in the communicative spontaneous inferences that occur in communication are built up by logical rules in the formation of interpretive hypotheses; b) suppositions comprising creative reasoning, analogue and associative, can be confirmed by non-logical operations with free access to information conceptually represented in the memory: c) these are non-demonstrative and non-trivial inferences once they cannot be logically demonstrated, but only confirmed and d) they do not present pre-established premises in the derivation of valid conclusions .

We claim that with relevance theory it is possible to explain the intricate structure of communicative pieces stressing explanatory mental aspects and perceptual factors necessary for more efficient production and reception of the possible advertising discourse. To Sperber and Wilson, mental effort inherent to human cognition must be in a balanced relationship with the effects achieved in understanding the intended message, once human cognition tends to be geared to the maximization of relevance (WILSON; SPERBER, 2004, p. 254). To them, human beings automatically aim at the most efficient processing of information for human interaction. This cognitive feature is also present in the communicator, in this case, the advertiser, when he creates a text in an intentional and ostensive way, because, according to the authors of Relevance,

\footnotetext{
the universal cognitive tendency to maximise relevance makes it possible, at least to some extent, to predict and manipulate the mental states of others. Knowing of your tendency to pick out the most relevant stimuli in your environment and process them so as to maximise their relevance, I may be able to produce a stimulus which is likely to attract your attention, to prompt the retrieval of certain contextual assumptions and to point you towards an intended conclusion. (WILSON; SPERBER, 2004, p. 671)
}

It is the communicative process aiming at information efficiency and economy the main focus of our analysis in this paper. 
The success of an advertising campaign is reflected in the ability to convince/persuade the audience to choose the product or, at least, registering a mark, service or idea in their memory that will surface at the time of purchase.

Sant'Anna (2002, p. 151) summarizes this question emphasizing that

\begin{abstract}
The purpose of advertising is purely and simply to communicate to a specific audience an idea and information that will trigger an action. ${ }^{3}$ Success or failure in advertising depends on the way it conveys the desired information and attitudes to the adequate audience in a specific time at a right cost.
\end{abstract}

The first step of this process is grasping the consumer's attention, since advertising is interaction, aiming to create a response in someone. Therefore it involves active participation between communicator and recipient.

It is worth pointing out that for Wilson and Sperber (1986, p. 71),

there are always alternative ways of interpreting a given piece of evidence, even when all the correct procedures for interpretation are applied and therefore there is always an element of risk.

By following this path, we cannot forget that in the communicative process the audience interests, their knowledge of the world, their ways of life, cognitive abilities must also be considered. Thus it is justifiable to say that communication is heavily dependent on the relevance expectations of the audience. But it is also possible to say that communication depends on the abilities of humans to recover implicit contextual suppositions and derive implicit conclusions. As Silveira (2005, p. 124) points out a communicative piece does not give all information needed for its understanding. In his interpretive process, the individual must retrieve implicit elements, forming inferences so that he can fill out what is not explicit, in an exploratory mental activity that can effectively lead him to understand what he sees/reads/listens.

In creating advertising pieces, each and every resource used-image, speech, writing or auditory stimulus - must presuppose the way the receiver/recipient will understand the message in order to come to an adequate interpretation. In other words, apart from not being at random, the choice of resources must be constrained by the target audience in the search for successful communication. Basically, the elements that constitute the communicative pieces are linked or refer to information stored in the memory of individuals through possible mental associations, allowing them to develop an inferential process of understanding, drawing on perceptual and cognitive abilities. To Sperber and Wilson (1995), this interpretive process is based on the central theoretical notion of mental context, a psychological construct that explains how stored information in the mind of the individuals are selected and surface during communicative interaction.

\footnotetext{
3 Translated from the original: A tarefa da publicidade é, pura e simplesmente, a de comunicar, a um público determinado, informações e uma ideia que estimule a ação. A publicidade obtém ou não êxito, segundo ela comunique bem ou mal a informação e atitudes desejadas, ao público adequado, no momento apropriado e a um custo exato.
} 
Assuming then the assumption that pragmatic comprehension processes are highly context dependent, once different contextual information will lead to different pragmatic interpretations, it is crucial to select the context in which the assumptions are processed and this context may include besides information retrieved from the mental encyclopedia, information from the physical environment and short-term memory (recently processed) of the audience.

Considering media in general, any advertising text is structured in a set of meaningful images, sounds, verbal texts and actions that help its understanding and involve a common goal: to reach the consumer, drawing his attention. Thus, the use of such resources should not be casual, but marked by intentionality designed to surprise, to shock or to compare in order to make the text ostensive, often demanding extra effort in information processing. According to Tanaka (1992, p. 101), the extra processing effort involved may be said to be the price the advertiser has to pay to get his message noticed at all, or else the audience could ignore the message and no effect would be achieved. In addition, this extra processing effort is compensated by increasing the strength of the transmitted message or by keeping it longer in the audience's minds.

Thus it follows the importance of caring about the audience in the advertising process, as it is the audience who will reflect the success of any advertising through their acceptance of the product. Moreover, as Day (1984) states, if the product is not perceived as being sufficiently relevant to enough people, the product dies [...] the product must be relevant to the way people live, which means the communication must start from a common point of reference.

And Relevance Theory may explain this point of reference theoretically. Following Sperber and Wilson's (apud SILVEIRA, 2008, p. 21) cognitive approach to human communication, it is possible to say.

\begin{abstract}
that advertisers are constrained by the audience relevance expectation. The advertiser that does not follow this lead may fail to be understood and convey their communicative purpose; thus it is the audience expectation that must trigger the creation of advertising pieces. ${ }^{4}$
\end{abstract}

Moreover, taking into consideration that any advertisement can be somehow intrusive, uninvited and parasitic on other discourse types (COOK, 1992, p. 199) it is quite important that advertisers know how to use ostensive stimulus in order to get the audience's attention. Sperber and Wilson state that once relevance is a basic feature of human cognition, it is expected that one pays attention to phenomena or stimuli that seem relevant to them or, in other words, humans are driven to what interests them, and tries to get the most of contextual and cognitive effects with the least effort needed to process information. Sant'Anna (2002, p.115) seems to corroborate this characteristic

\footnotetext{
4 Translated from the original: [...] os falantes, neste caso os publicitários, são restringidos pela expectativa de Relevância do ouvinte, o público-alvo. O falante publicitário que não faz esforço para adaptar-se a essa expectativa, arrisca-se a ser mal compreendido, não atingindo o seu propósito comunicativo; portanto, é a expectativa de Relevância do consumidor destinatário que deve constituir o alicerce para a criação de peças de publicidade.
} 
affirming, "The human spirit only detains itself on what it is personally and directly interested on, deviating from what does not captivate its attention. The interest one person directs to an object of its voluntary attention is a function of the value that the object represents to them.",

The resources used constitute, within the perspective of Relevance theory, ostensive stimuli to unleash inferences in the most attentive spectator. Meaning will be built, then, from contextual cues that will make up the premises for the probable interpretation through an inferential deductive calculus.

As known, in the authors' theoretical framework there is no normative character of previous obedience to principles for communication to be successful, but there is the approach to the way human beings represent and process information in their mind, in a natural and spontaneous way, once verbal comprehension takes place through the search for Relevance, an innate property of mental processes.

Sperber and Wilson describe and explain in their theory how the speaker/author attracts the listener/reader's attention through an ostensive stimulus, and how this listener/reader performs his task — which is essentially inferential-for verbal and nonverbal comprehension.

Information is thus restricted by a principle of [cognitive] economy, based on a property of mental processes inherent to human comprehension. According to this cognitive-based Principle of Relevance, the addressee selects the most accessible context to get contextual effects from the information received. In other words, if the context reveals adequate contextual effects, this interpretation is consistent with the Relevance Principle. Furthermore, what makes an input worth picking out from the mass of competing stimuli is not just that it is relevant, but that it is more relevant than any alternative input available to us at that time.

The Principle of Relevance has the potential to explain how, among many pragmatic interpretations compatible with the linguistic decoding of an utterance or an image, for example, only one is selected in the process of understanding. Innate to human cognition, it seems to be determinant in explaining the universality of inferential processes; it governs the ostensive and intentional behavior of the communicator in a way that the recipient/audience may get the required information with the lowest possible cost, by selecting right suppositions and contexts to the interpretation. This principle thus aims to explain the inferential communication as a whole, both explicit and implicit. It is applied without exception, in every act of ostensive communication.

Considering these observations, it is here proposed the application of Relevance Theory assumptions to the interpretation of the advertisement pieces here selected, with the aim to demonstrate how the ostensive-inferential process takes place as it is conceived within the conceptual architecture of Relevance.

\footnotetext{
5 Translated from the original: "O espírito humano só se detém naquilo que lhe interessa pessoal e diretamente, desviando-se do que não cativa a sua atenção. $O$ interesse que uma pessoa dirige a um objeto de sua atenção voluntária é uma função do valor que este objeto representa para ela".
} 
It is, therefore, a case of presenting a theoretical-applied contribution, emphasizing cognitive processes of inferential nature that are involved particularly in textual comprehension and interpretation, from communicational assumptions grounded in natural properties of human cognition. To put it differently, we will exemplify textual comprehension through relations of Relevance, associated with efficiency and economy of information.

\section{EXEMPLIFYING}

The objects of our analysis are three different pieces of advertising aiming at distinct audiences with varied purposes. None of them engage in selling marketing products; they promote ideas and make use of both images and linguistic input for conveying their messages.

\section{A) UNICEF CAMPAIGN}

The first piece is a billboard from $\mathrm{UN}$ and $\mathrm{UNICEF}^{6}$ in their campaign for inviting people to support a campaign against the recruitment of children in armed conflicts (see figure 1).

\section{Figure 1 - Billboard from UN and UNICEF}

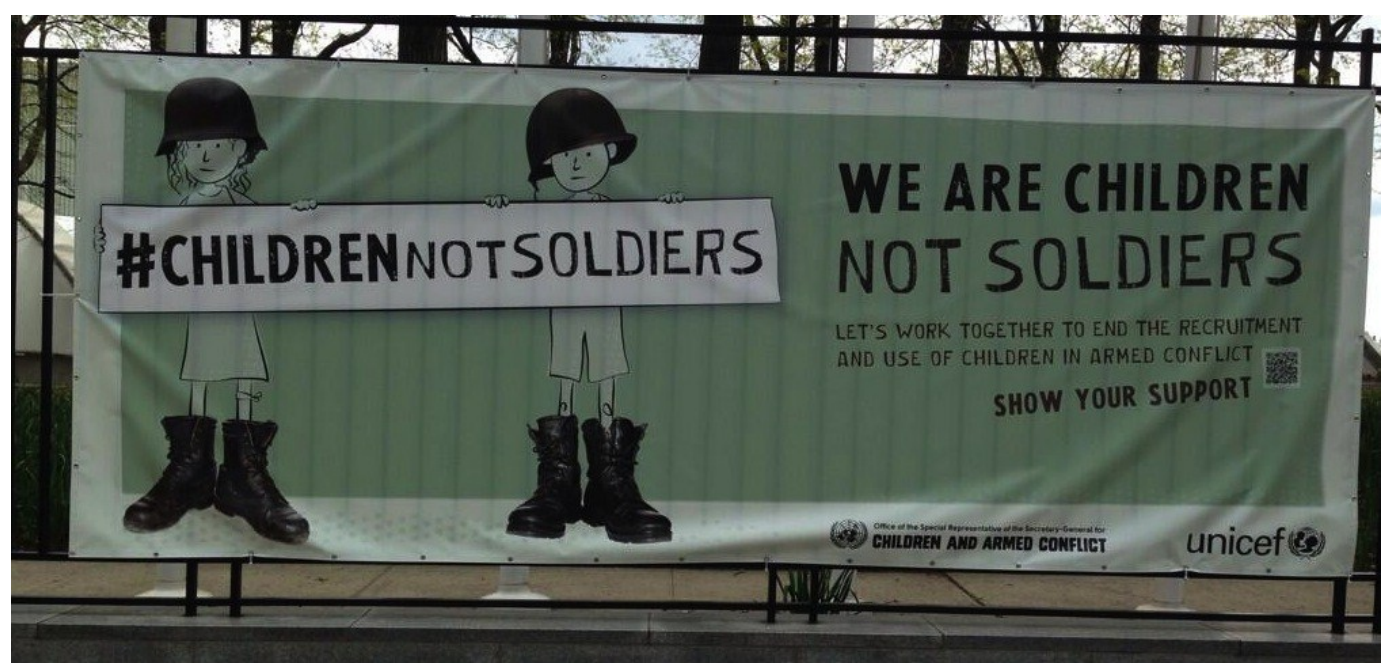

It is worth mentioning, following ideas from Ellestron (2010), the contextual qualifying aspect of the advertising; that is, the origin, delimitation and use of media in specific historical cultural and social circumstances. Something advertised by UNICEF already gives the reader/addressee basic plain information: "it must be related to children because that is what UNICEF does". Moreover, it is common knowledge (at

\footnotetext{
${ }^{6}$ Billboard near The United Nations Headquarters in New York.
} 
least conveyed every day in the media) that there are armed conflicts everywhere. As Forceville (2012) points out, the pictorial message comes with the presumption of relevance; all signal: "hey, look at me, I'm worth your attention". Besides, billboards have the advantage of being huge and eye-catching, targeting different classes, thus having a guaranteed audience.

The analysis could be threefold: a) the written language, b) the picture and c) the merger of the two.

Even with this primary division, it is also important to note that both a) and b) could also be subdivided. Concerning a) we should pay attention to typography and the relevance it has for conveying ideas and information. There are capital letters but also bold letters and different font sizes. What comes out first in the billboard in terms of caption is \#CHILDREN and WE ARE CHILDREN in bold capital letters, followed by NOT SOLDIERS. The fact that 'children' is in bold but 'soldiers' not can trigger the importance of the first concept in relation to the second giving rise to a possible inference such as being children.

Considering that the billboard was placed in New York City, it is safe to say that it would be obvious to a regular passer-by that children are not soldiers. Thus, it would be possible to question the informative intention of these captions. This advertisement makes manifest a communicative intention.

As Wilson and Sperber (2004, p. 251) state the most important type of cognitive effect achieved by processing an input in a context is a contextual implication, a conclusion deducible from the input and the context together, but from neither input nor context alone. The simple change from bold capital letters to capital letters suggests a downgrading in the importance of the words that follow. What matters is to be a child, nothing else and to be a child is to be happy, to play and face life in a nice way. WE ARE CHILDREN evokes a tautology "children are children" that can give rise to different assumptions, rhetorically speaking. Together with the picture of a girl and a boy with possibly sad faces wearing oversized army helmets and combat boots and holding the twitter address, a set of assumptions is made manifest both with informative and communicative intention: children do not belong in war, therefore, something must be done. Go! Tweet the hashtag and give UNICEF support. Both Cognitive and Communicative Principles are at play; the kinds of evidences provided by the billboard yields positive cognitive effects, that is, a contextual implication, a conclusion deducible from the input and the context together, but from neither input nor context alone (SPERBER; WILSON, 1995, §3.1-2)

More could be said about the billboard, the relevance of the over-sized boots and helmet, for instance, according to Billy Clark $^{7}$, suggests assumptions about innocence and fragility of children and how adults in contexts without child soldiers would view something like this (playing, dressing up in grown-up clothes, etc.) contrasting with the horrors of actual child soldiers, which would give rise to a range of weak implicatures which leads to emotive effects we could also develop the idea of path $s$ taken from Aristotle, in the sense that the arguments present in this specific piece of work are based

\footnotetext{
${ }^{7}$ Personal communication on $21 / 09 / 214$.
} 
on appealing to feelings or emotions and so on, but the purpose of this analysis was to show the merging of picture and linguistic stimuli as a matter of making the most efficient use of the available processing resources to achieve the intended effects.

\section{B) FUNDAÇÃO PRÓ-SANGUE - PRÓ-SANGUE FOUNDATION}

The second piece to be analyzed was designed by Agência Publicis for Fundação Pró-Sangue (Pró-Sangue Foundation), São Paulo, Brazil, as an out of home advertising to encourage people to give blood (see figure 2).

One can observe in this piece that the presence of verbal text and image complement each other, making it easy for the adequate comprehension. Such resources constitute ostensive stimuli to the receiver, and they will be processed in the context of the information that becomes available.

The image of a stretched arm, with a red wire coming out of its vein, evoking the idea of blood donation, is attached to the act of recharging a cell phone's battery, which is connected to the end of the wire. Even though "to donate blood" and "to recharge a cell phone" apparently cannot have any meaningful relation, thanks to the contextual information, the images, when associated to the verbal context or linguistic input allow easily for one to build the supposition: the receiver can reciprocate the freely available service of recharging his cell phone battery with a spontaneous action of donating blood.

This concerns two needs that, even if different in nature and, obviously, in their proportion - a fact that is prominent due to the size of the images of the arm and the cell phone-are very common in the current context: people in need of blood to be kept alive and people in need of a working cell phone to keep in touch with the world.

It is made clear here Sant'Anna's (2002) statement concerning the fact that the human spirit only lingers on what is interesting to it on a personal and direct level, deviating from what does not captivate its attention or, in terms of S-W, the cognitivecommunicative assumption that human beings pay attention to what meets, in some way, their needs and wills.

According to the authors of Relevance, information deliberately addressed to us must be sufficiently relevant, that is, rich enough in contextual effects and economical enough in terms of processing in order to create an assumption of Relevance and be worthy of our attention. In this sense, besides the visual and linguistic stimuli, the interactive property of this campaign constitutes a very ostensive way of getting one's attention. The text- "If you need us, we are here. Why not reciprocate? We need blood."-presupposes direct and intentional communication with the people that face it, especially with the appeal within the rhetorical question, that causes the receiver to automatically create expectations that lead him towards the communicator's meaning.

As Menna Barreto (2004) points out, there are countless creative approaches to implement good communication solutions, and what we can see in this piece is exactly creativity in the name of a well done efficient and economic piece of communication; the advertiser allows for the target audience to reach the cognitive-contextual effects aimed for, at low mental cost in the inferential processing of information. 
Figure 2: Piece from Fundação Pró-Sangue (Pró-Sangue Foundation)

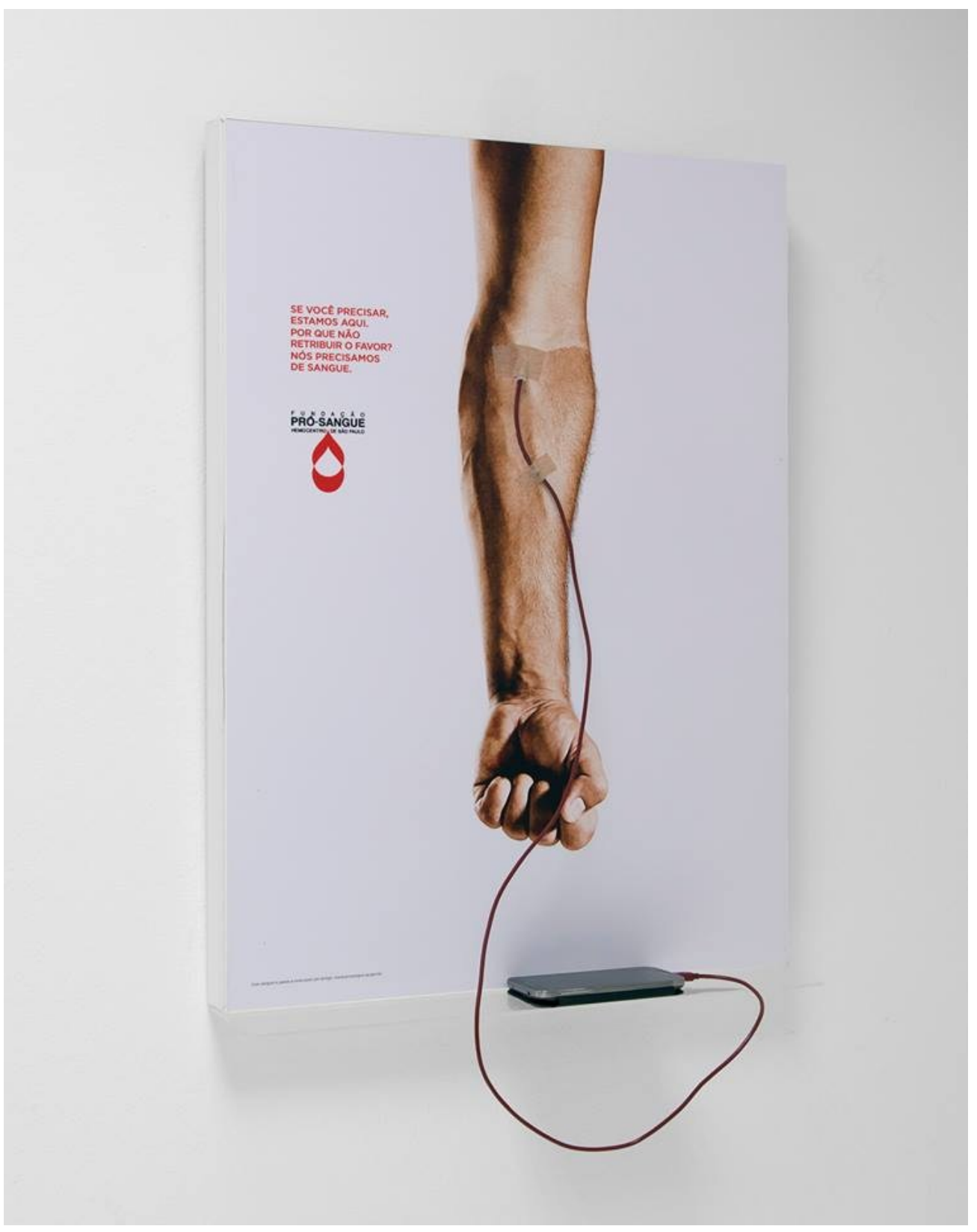

C) USE FONES DE OUVIDO NO ÔNIBUS - USE EARPHONES IN THE BUS

The last analysis to be developed concerns an educational campaign, whose objective is to remind passengers to use earphones when in public transportation vehicles in the city of Porto Alegre, Rio Grande do Sul, Brazil (see figure 3). ${ }^{8}$

\footnotetext{
${ }^{8}$ This campaign is a joint action of ATP (Associação dos Transportadores de Passageiros - Passengers' Transportation Association), Cia. Carris Porto-Alegrense and EPTC (Empresa Pública de Transporte e Circulação - Public Transportation and Circulation Company), and was developed to help to enforce a city law of Porto Alegre, the Complementary Law \#689, of February $15^{\text {th }}, 2012$, that alters the Behavioral Code of Porto Alegre, establishing as an infraction the non-use of earphones when using sound equipment inside public transportation vehicles. This information is placed at the bottom part of the stickers.
} 
Figure 3: Campaign "Use earphones in the bus"

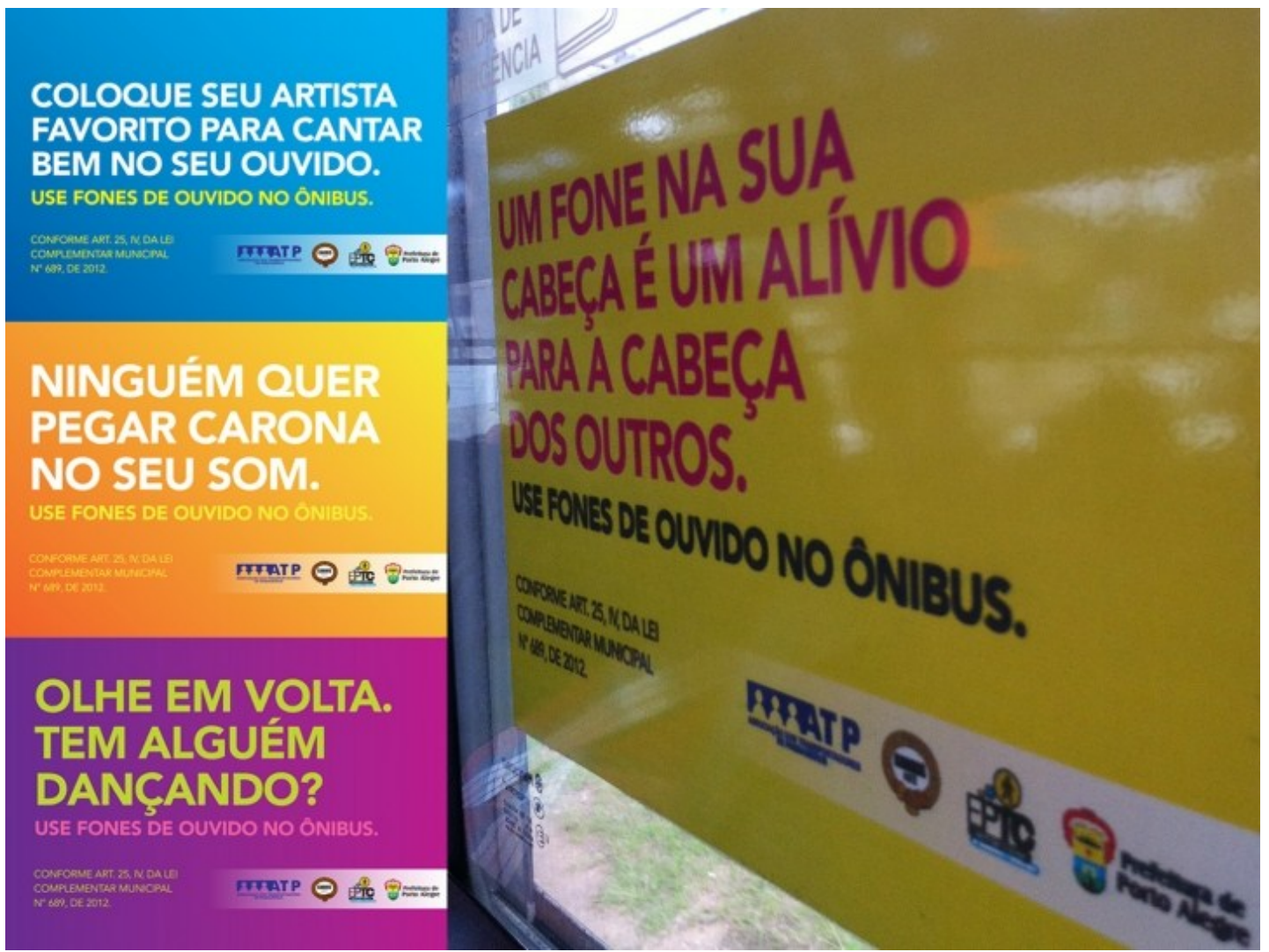

It is made of size A4 stickers of different types created with different colors and sentences highlighted in bigger font, which are always followed by what represents the key message of the campaign- USE FONES DE OUVIDO NO ÔNIBUS (Use earphones in the bus), as can be observed in the four selected pieces.

Differently from the other pieces here analyzed, these do not present image as ostensive stimulus being up to the verbal text to get the receiver's attention. In the highlighted sentences, marked by the presence of irony, there is no direct semantic relation with the use of the mentioned devices, except for sticker 4 - "UM FONE NA SUA CABEÇA É UM ALÍVIO PARA A CABEÇA DOS OUTROS”. However, when associated to the sentence that follows them and to the contextual information from the observable context, can lead to low cost inferential comprehension by creating, with the smallest load of mental processing, an assumption of Relevance for the receiver.

In this way, in the first sticker, the linguistic input-Coloque seu artista favorito para cantar bem no seu ouvido (Get your favorite artist to sing in your ear)—becomes an ostensive stimulus when leading the receiver to the idea of closer contact with his favorite singer, what can surely constitute a pleasant situation. It also seems that there is the possibility of double meaning in the expression "sing well", that is, besides singing well close to you, it can also mean to sing distinctively well, both meanings being favorable to the intended message, once they suggest the use of earphones. 
In the second sticker, the sentence-Ninguém quer pegar carona no seu som (Nobody wants a ride with your sound)-when contextualized with information available in the reader's encyclopedic memory, easily allows for the comprehension that the sound that one wants to hear does not need to reach the other people or, at least, the people around us, once more indicating that the receiver, when using earphones, will not need to share with others what he is listening to.

A rhetorical question, in the third sticker-Olhe em volta. Tem alguém dançando? (Look around. Is there anyone dancing?)—indicates intentional communication, seeking interaction with each reader. It is possible to notice the direct relation with the information stored in the encyclopedic memory that the rhythm of a song that we like may constitute as stimulus to dancing. Being that nobody is dancing, since people do not usually dance on a public transportation bus, it is therefore no appropriate place to share music with people, which can be avoided with the use of earphones.

Finally, in the last sticker, the sentence-Um fone na sua cabeça é um alivio para a cabeça dos outros. (Earphones on your ears are a relief for everybody else's) -leads, more explicitly, to the comprehension that the earphones allow one to listen to sound without bothering the others around us with our choice, considering that one's preferences are not always compatible with other people's.

It is possible to affirm that the objective of inferential pragmatics, more specifically, of the theoretical approach of Relevance, which is to explain how a receiver infers the communicator's meaning with basis on the evidence/stimuli provided, was contemplated satisfactorily in this campaign. The sentence USE FONES DE OUVIDO NO ÔNIBUS (USE EARPHONES IN THE BUS) alone would not have had the same ostensive effect to unleash the needed inferential processing, aiming at making the action effective, that is, to make the bus users think about the importance of using such devices when riding the public vehicles. In addition, this action is obviously reinforced/strengthened by the information that it is about a law, as shown in the bottom left corner of all the pieces.

Going back to Tanaka's (1994) claim, the extra processing effort required for the comprehension of ostensively marked sentences might be the most adequate way for a publicist to get one's attention to his message and to guarantee that it is inferentially processed by the receiver that, when getting to bigger cognitive-contextual effects, might keep them in memory for longer and respond positively to what has been communicated.

\section{CONCLUSION}

In this paper, we have briefly presented the foundations of Relevance theory with inferential process in mind, that is, as Sperber and Wilson point out through their work, every act of inferential communication creates an expectation of optimal relevance, in the light of which hypotheses about the intended interpretation can be evaluated.

Our main line of thought is that we can explain inferences of natural language through the concepts of Relevance Theory whose main foundation is that human beings 
rely on interpretive principles to select the interlocutor's intended interpretation. The samples analyzed showed that the need of a pragmatic interpretation for a real understanding requires the presence of a context and of inferential processes that cannot be performed simply in terms of a code. Thus, communication is not achieved by encoding and decoding messages, but by providing contextual clues to build the desired inference about the intentions of the communicator

If communication in general works the way Sperber and Wilson present in their theory, we also claim that advertisers are constrained by the audience's expectation and that the maximization of relevance in the case of advertisement pieces may require more than the balance between the usual cost and benefit (cognitive effects and mental effort). However, we sustain that even if the costs of processing inferences are higher than expected, it is surely possible to notice that the advertising message conveyed in each of the three pieces analyzed reaches optimal relevance, inasmuch as the mental effort was balanced by plausible contextual effects to be obtained selected according to the consistency criteria with the relevance principle. Anyway, relevance is the goal and it will stand out among other possible interpretations that lurk around.

\section{REFERENCES}

COOK, G. The Discourse of Advertising. London: Routledge, 1992.

DAY, B. Foreword. In: DOUGLAS, T. The Complete Guide to Advertising. London: MacMillan, 1984. p. 6-9.

ELLESTRÖM, L. (Ed.). Media Borders, Multimodality and Intermediality. Basingstoke: Palgrave MacMillan, 2010.

FORCEVILLE, C. Relevance Theory as Model for Analyzing Visual and Multimodal Communication: (version 28/12/12). Available at:

$<$ http://muldisc.files.wordpress.com/2013/08/chf20chapter20for20machin20ed202720dec20201220mouto n20style20distributed20version.pdf $>$. Access on: 24 May 2014.

MENNA BARRETO, R. Criatividade em propaganda. 12. ed. São Paulo: Summus, 2004.

SANT’ANNA, A. Propaganda: teoria, técnica e prática. 7. ed. São Paulo: Pioneira, 2002.

SILVEIRA, J. R. C. da. A imagem: interpretação e comunicação. Linguagem em (Dis)curso, v. 5, p. 113 128, 2005.

Publicidade: uma questão de relevância. In: VIII Encontro do Celsul, 2008, Porto Alegre. Anais do CELSUL, 2008. Porto Alegre: UFRGS, 2008.

SPERBER, D.; WILSON, D. Relevance: Communication and Cognition. 2nd. ed. Cambridge, Massachusetts: Harvard University Press, 1995.

TANAKA, K. The Pun in Advertising: a Pragmatic Approach. Lingua, n. 87, 1992.

. Advertising Language: a Pragmatic Approach to Advertisements in Britain and Japan. London: Routledge, 1994.

WILSON, D.; SPERBER, D. Pragmatics and modularity. In: Chicago Linguistic Society Parasession on Pragmatics and Grammatical Theory, p. 67-84.

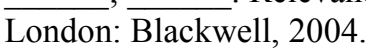

Relevance Theory. In: HORN, L.; WARD, G. (eds.). The Handbook of Pragmatics.

Relevance Theory. Available at:

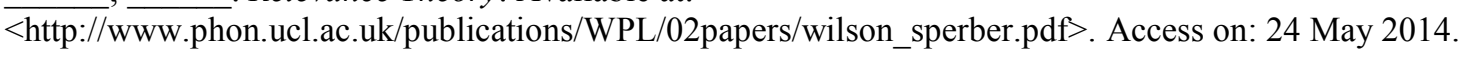


Recebido em 30/06/14. Aprovado em 08/10/14.

Título: Inferências em peças publicitárias: exemplificando com a Teoria da Relevância Autoras: Jane Rita Caetano da Silveira e Ana Maria Tramunt Ibaños.

Resumo: Desde que Sperber e Wilson apresentaram sua teoria sobre Relevância, muito foi feito ou para corroborar ou para refutá-la como a melhor teoria sobre comunicação disponivel. O que se sabe é que, através dos anos, não somente linguistas, mas também teóricos das ciências cognitivas têm aplicado os princípios da Teoria da Relevância para explicar fenômenos relativos à comunicação humana. E o nosso trabalho não é diferente, ele discute as possibilidades de se analisar peças publicitárias centradas em elementos visuais e verbais através da Teoria da Relevância de Sperber e Wilson. Mais especificamente, visamos à análise dos elementos desencadeiam a compreensão inferencial. As três peças escolhidas para a exemplificação não são típicas peças publicitárias que visam à venda de um produto, mas, sim, vendem ideias através do amálgama de inputs linguísticos e visuais.

Palavras-chave: Teoria da Relevância. Comunicação. Inferência. Propaganda.

Título: Inferencias de la publicidad: ilustrando con la Teoría de la Relevancia Autoras: Jane Rita Caetano da Silveira y Ana Maria Tramunt Ibaños.

Resumen: Desde que Sperber y Wilson presentaron la teoría sobre Relevancia, muchos trabajos académicos fueron hechos, sea para corroborarla o refutarla como la mejor teoría sobre comunicación disponible. Lo que se sabe es que, a través de los años, no solo los lingüistas, pero también los teóricos de las ciencias cognitivistas han aplicado los principios de la Teoría de la Relevancia para explicar fenómenos relativos a la comunicación humana. Así que nuestro trabajo no es distinto; nuestro artículo discute las posibilidades de analizar los anuncios publicitarios centrados en elementos visuales y verbales a través de la Teoría de la Relevancia de Sperber y Wilson. Más específicamente, nuestro objetivo es analizar los elementos que desencadenan la comprensión inferencial. Las tres piezas elegidas para la ejemplificación no son campañas de publicidad destinadas a vender un producto, sino que venden ideas a través de la fusión de las entradas lingüisticas y visuales.

Palabras-clave: Teoría de la Relevancia. Comunicación. Proceso inferencial. Anuncio publicitario. 